\title{
The origins of ice crystals measured in mixed-phase clouds at the high-alpine site Jungfraujoch
}

\author{
G. Lloyd ${ }^{1}$, T. W. Choularton ${ }^{1}$, K. N. Bower ${ }^{1}$, M. W. Gallagher ${ }^{1}$, P. J. Connolly ${ }^{1}$, M. Flynn ${ }^{1}$, R. Farrington ${ }^{1}$, \\ J. Crosier ${ }^{1,2}$, O. Schlenczek ${ }^{3,4}$, J. Fugal ${ }^{3,4}$, and J. Henneberger ${ }^{5}$ \\ ${ }^{1}$ Centre for Atmospheric Science, University of Manchester, Manchester, UK \\ ${ }^{2}$ NERC National Centre for Atmospheric Science (NCAS), Manchester, UK \\ ${ }^{3}$ Particle Chemistry Department, Max Planck Institute for Chemistry, Mainz, Germany \\ ${ }^{4}$ Institute for Atmospheric Physics, Johannes Gutenberg University, Mainz, Germany \\ ${ }^{5}$ ETH, Zurich, Institute for Atmospheric and Climate Science, Universitätsstraße 16, 8092, Zurich, Switzerland
}

Correspondence to: G. Lloyd (gary.lloyd@ manchester.ac.uk)

Received: 2 June 2015 - Published in Atmos. Chem. Phys. Discuss.: 7 July 2015

Revised: 8 October 2015 - Accepted: 29 October 2015 - Published: 24 November 2015

\begin{abstract}
During the winter of 2013 and 2014 measurements of cloud microphysical properties over a 5-week period at the high-alpine site Jungfraujoch, Switzerland, were carried out as part of the Cloud Aerosol Characterisation Experiments (CLACE) and the Ice Nucleation Process Investigation and Quantification project (INUPIAQ). Measurements of aerosol properties at a second, lower site, Schilthorn, Switzerland, were used as input for a primary ice nucleation scheme to predict ice nuclei concentrations at Jungfraujoch. Frequent, rapid transitions in the ice and liquid properties of the clouds at Jungfraujoch were identified that led to large fluctuations in ice mass fractions over temporal scales of seconds to hours. During the measurement period we observed high concentrations of ice particles that exceeded $1000 \mathrm{~L}^{-1}$ at temperatures around $-15^{\circ} \mathrm{C}$, verified by multiple instruments. These concentrations could not be explained using the usual primary ice nucleation schemes, which predicted ice nucleus concentrations several orders of magnitude smaller than the peak ice crystal number concentrations. Secondary ice production through the Hallett-Mossop process as a possible explanation was ruled out, as the cloud was rarely within the active temperature range for this process. It is shown that other mechanisms of secondary ice particle production cannot explain the highest ice particle concentrations. We describe four possible mechanisms that could lead to high cloud ice concentrations generated from the snowcovered surfaces surrounding the measurement site. Of these we show that hoar frost crystals generated at the cloud en-
\end{abstract}

veloped snow surface could be the most important source of cloud ice concentrations. Blowing snow was also observed to make significant contributions at higher wind speeds when ice crystal concentrations were $<100 \mathrm{~L}^{-1}$.

\section{Introduction}

During January and February 2014 the Ice Nucleation Process Investigation and Quantification (INUPIAQ) project took place at three high-alpine sites in the Swiss Alps: Jungfraujoch $\left(46.55^{\circ} \mathrm{N}, 7.98^{\circ} \mathrm{E}\right)$, Schilthorn $\left(46.56^{\circ} \mathrm{N}\right.$, $\left.7.84^{\circ} \mathrm{E}\right)$ and Kleine Scheidegg $\left(46.59^{\circ} \mathrm{N}, 7.96^{\circ} \mathrm{E}\right)$, Switzerland, as part of the Cloud Aerosol Characterisation Experiment (CLACE) 2014. Previously, during the same months of 2013, measurements were made as part of CLACE at the Jungfraujoch site only. There are comparatively few detailed measurements of cloud microphysical properties at mountain top sites, particularly in supercooled conditions. Choularton et al. (2008) presented data from earlier CLACE experiments that took place at Jungfraujoch (JFJ) in which ice particle number concentrations and habit were measured with a Cloud Particle Imager (CPI, SPEC Inc., USA) probe, water droplets with a Forward Scattering Spectrometer Probe (FSSP-100, DMT, USA) and liquid water content with a Particulate Volume Monitor (PVM-100, Gerber Scientific). They observed rapid transitions between liquid and glaciated cloud that took place on spatial scales of just a few metres. 
Similar fast transitions over temporal scales $\sim 1 \mathrm{~s}$ have been observed in other atmospheric settings during airborne measurement campaigns (e.g. Lloyd et al., 2014).

As well as very rapid phase transitions measured in the clouds at JFJ there were also changes that took place over longer temporal scales (several hours) during the campaign period. Henneberger et al. (2013) made measurements with a holographic instrument and also observed a transition from mixed-phase to glaciated cloud over a larger temporal scale of $8 \mathrm{~h}$. Choularton et al. (2008) showed that strongly glaciated cloud periods at JFJ were linked to polluted air masses, characterised by higher loadings of sulphate, arriving at the site. Clouds were found to contain variable ice number concentrations measured by various cloud imaging probes, often in the range $1-1000 \mathrm{~L}^{-1}$. Targino et al. (2009) also found that higher loadings of organic, inorganic and black carbon aerosol were associated with an increase in the lifetime of glaciated cloud periods. Concentrations of ice were again sometimes observed in excess of $1000 \mathrm{~L}^{-1}$. Rogers and Vali (1987) made ground-based and airborne measurements of orographic wave clouds in contact with the ground at the Elk Mountain Observatory, Wyoming. Similar concentrations of ice were present in these mountain cap clouds that were in contact with the snow-covered mountain surface but they discounted blown snow as a contributor as the observed ice crystal sizes and shapes were not consistent with this process.

Under conditions where heterogeneous ice nucleation dominates, the concentration and composition of aerosol particles in the atmosphere are likely to significantly influence the number and variability of ice particles. Measurements of cloud particle (liquid droplet and ice crystal) residuals at JFJ have been found to be enriched in chemical species such as mineral dust (Kampphus et al., 2010; Schmidt et al., 2015), including lead with complex internal mixtures of silicates and metal oxides, secondary aerosol and carbonaceous material (Ebert et al., 2011) compared to the cloud interstitial aerosol (un-activated aerosol particles). This previous work suggested that particles from industrial activity containing lead were especially important as ice nuclei (IN) along with contributions from dust and organic material. At the time it was suggested that admixtures of these anthropogenic components may have been responsible for the increased IN efficiency and hence observed concentrations within mixedphase clouds. Sampling of aerosol at JFJ and testing for IN active particles to determine an IN concentration has also shown significant seasonal variability linked to changes in aerosol source. Chou et al. (2011) used a portable ice nucleation chamber (PINC) to make the first continuous measurements of IN over a period of days at JFJ. They found a mean IN concentration of $8 \mathrm{~L}^{-1}$ during a winter measurement period and $14 \mathrm{~L}^{-1}$ during the summer. They also identified a Saharan dust event (SDE), where IN concentrations were seen to increase to several hundred per litre. During the
SDE they found the IN to be correlated with larger aerosol particles $>0.5 \mu \mathrm{m}$ in size.

\section{Motivation for INUPIAQ and CLACE Experiments}

CLACE is a long-standing series of experiments at JFJ aiming to improve understanding of aerosol particles in the atmosphere that act as cloud condensation nuclei (CCN) and IN, contributing to the aerosol-cloud indirect effects (Lohmann and Feichter, 2005). These aerosol particles influence the optical properties of clouds, their lifetimes and precipitation. A lack of knowledge about CCN and the abundance and efficiency of atmospherically relevant IN, together with the role of secondary ice production, is a major source of uncertainty in assessing anthropogenic climate change. For example, due to the current uncertainty about IN in the atmosphere, the Intergovernmental Panel on Climate Change (IPCC) only include simple radiative forcing estimates for ice clouds.

Another key objective was to confirm the structure of the previously observed transitions between ice and liquid clouds. These fluctuations in ice and liquid water provide information about whether ice particles and liquid droplets are mixed together or isolated in glaciated and unglaciated regions, respectively.

During INUPIAQ (2014) we used measurements from JFJ and Schilthorn sites. The aim of these measurements was that the lower Schilthorn site would act as an upwind site to measure the properties of the aerosol in order to examine the influence of these on the prevailing downwind cloud microphysics at the summit of JFJ. In the CLACE2013 experiment the set-up was very similar to 2014 except that we only made measurements at the summit of JFJ.

\section{Measurement sites and instrumentation}

An overview of the locations of each site and a brief description of the instrumentation deployed and used in the analysis presented in this paper at each site is provided in this section. Figure 1 shows the locations of the sites that were used during the campaign.

\subsection{Jungfraujoch}

Jungfraujoch is situated high in the Swiss Alps, with measurements taken at the Sphinx laboratory at $3580 \mathrm{~m}$ a.s.l. (Fig. 1). Baltensperger et al. (1998) reported an annual mean cloud frequency of $37 \%$, at the site making it a suitable location for the study of long-term cloud microphysical properties of supercooled clouds in this region.

The JFJ measurement site was used primarily to measure cloud microphysical and residual cloud particle properties. An overview of relevant instrumentation at this site can be found in Table 1, and some of these instruments (that were mounted on a pan and tilt rotator wing) are labelled in Fig. 2. The rotator allowed us to automatically adjust the position of 


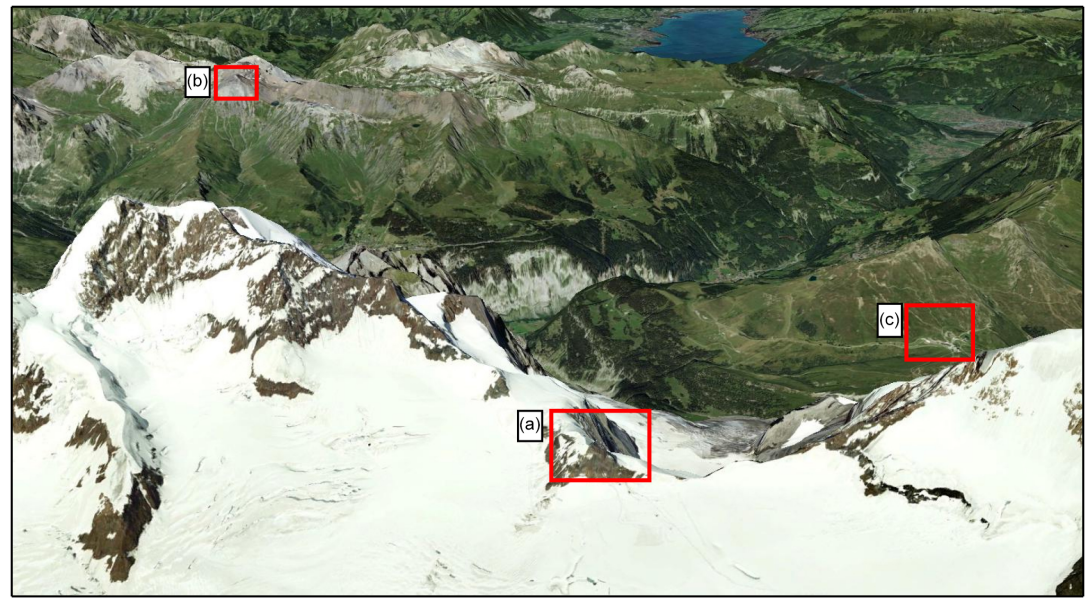

Figure 1. Satellite imagery showing the locations (red boxes) of Jungfraujoch (a), Schilthorn (b) and Kleine Scheidegg (c).

Table 1. A summary of the instrumentation deployed at the Jungfraujoch site including information about measurement type, method, size ranges and time resolution of the data provided.

\begin{tabular}{|c|c|c|c|c|}
\hline Instrument & Measurement & Method & Size range $[\mu \mathrm{m}]$ & $\begin{array}{l}\text { Time } \\
\text { Resolution }\end{array}$ \\
\hline CAS & $\begin{array}{l}\text { Aerosol and droplet size } \\
\text { distributions }\end{array}$ & $\begin{array}{l}\text { Optical diameter of particles de- } \\
\text { termined through scattered light }\end{array}$ & $0.51-50$ & $1 \mathrm{~Hz}$ \\
\hline CIP-15 & $\begin{array}{l}\text { Particle size distributions and } \\
\text { particle imagery }\end{array}$ & $\begin{array}{l}\text { Optical array probe ( } 64 \text { element } \\
\text { array at } 15 \mu \mathrm{m} \text { resolution) }\end{array}$ & $15-960$ & $1 \mathrm{~Hz}$ \\
\hline FSSP & Droplet size distributions & $\begin{array}{l}\text { Optical diameter of particles de- } \\
\text { termined through scattered light }\end{array}$ & $0.51-50$ & $1 \mathrm{~Hz}$ \\
\hline CDP-100 & Droplet size distributions & $\begin{array}{l}\text { Optical diameter of particles de- } \\
\text { termined through scattered light }\end{array}$ & $2-50$ & $1 \mathrm{~Hz}$ \\
\hline PVM & Liquid water content & Infrared extinction? & $3-50$ & $1 \mathrm{~Hz}$ \\
\hline $\begin{array}{l}3 \mathrm{~V}-\mathrm{CPI} \text { combining } \\
2 \mathrm{D}-\mathrm{S} \text { and } \mathrm{CPI} \\
\text { instruments }\end{array}$ & $\begin{array}{l}\text { 2D-S: particle size distributions } \\
\text { and shadow imagery } \\
\text { CPI: particle size distributions } \\
\text { and particle photographs }\end{array}$ & $\begin{array}{l}\text { 2D-S: optical array probe ( } 128 \\
\text { element array at } 10 \mu \mathrm{m} \text { effective } \\
\text { resolution) } \\
\text { CPI: use of a CCD camera to } \\
\text { photograph particles }\end{array}$ & $\begin{array}{l}\text { 2D-S: } 10-1280 \\
\text { CPI: } 2.8-2300\end{array}$ & $1 \mathrm{~Hz}$ \\
\hline Vaisala & Temperature and humidity & & & $1 \mathrm{~Hz}$ \\
\hline Metek & Wind velocity and direction & $\begin{array}{l}\text { Ultrasonic sound wave } \\
\text { measurement }\end{array}$ & & $1 \mathrm{~Hz}$ \\
\hline
\end{tabular}

the instruments based on information about the wind direction and vertical wind angle from a sonic anemometer. Measurements of cloud liquid water content (LWC) and droplet size distributions were provided by; a Particulate Volume Monitor (PVM, Gerber Scientific, Inc), which measured bulk LWC only (Gerber, 1991), Cloud Droplet Probe (CDP-100, Droplet Measurement Technologies, DMT) (Lance et al., 2010), Cloud Aerosol Spectrometer (CAS, DMT) (Baumgardner et al., 2001) and a Forward Scattering Spectrometer Probe (FSSP-100, DMT) (e.g. Dye and Baumgardner, 1984). Images of cloud hydrometeors for use in the ice/liquid phase and habit discrimination were provided by the 3 View-Cloud Particle Imager (3V-CPI, Stratton Park Engineering Company (SPEC) Inc, Boulder, Colorado). This instrument is comprised of a two-dimensional stereoscopic (2D-S) (Lawson et al., 2006) shadow imaging probe and a high frame rate ( 350 fps) CCD Cloud Particle Imager (CPI Model 2, SPEC Inc.) probe. A holographic cloud probe GipfelHolo from the Institute for Atmospheric Physics (IAP) - Max Planck Institute for Chemistry (MPIC) Mainz was also used to measure cloud particles. It is operated with a pulsed $355 \mathrm{~nm}$ UV laser, collimation optics and a 29 megapixel CCD detector with $5.5 \mu \mathrm{m}$ pixel width. In contrast to other instruments used during CLACE2013, this instrument was operated in an open path configuration as the sample volume is independent from the ambient wind speed. If an incident wave hits particles in the $3.6 \times 2.4 \times 35 \mathrm{~cm}^{-3}$ sample volume, the incident wave is partially diffracted and creates an interference 


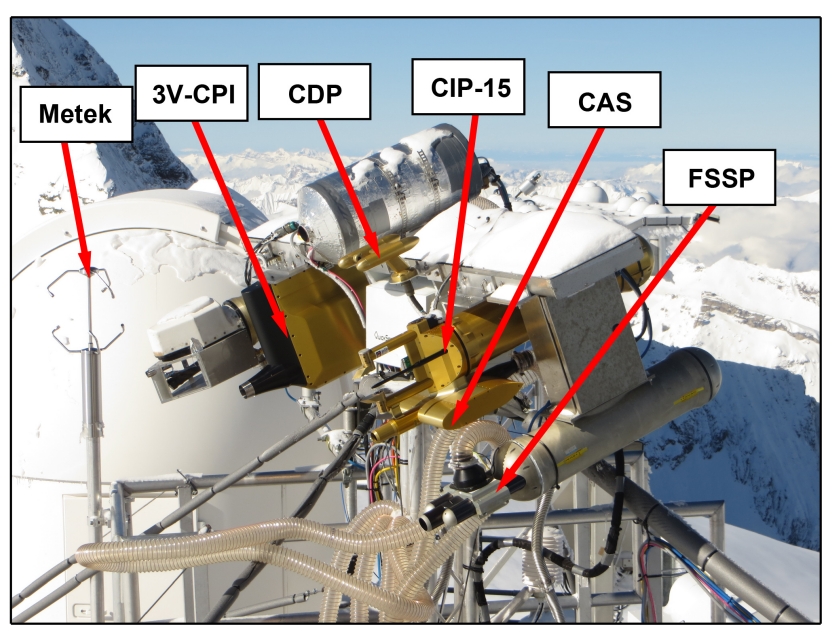

Figure 2. Photograph of the instruments mounted on a rotator and wing on the terrace rooftop outside the Sphinx Laboratory. INUPIAQ instruments include a sonic anemometer for measuring wind speed, 3V-CPI for cloud particle imagery, CDP for droplet measurements, CIP-15 for cloud particle imagery, CAS for droplet and aerosol measurements and an FSSP for droplet measurements.

pattern on the detector which is captured. The interference pattern (by definition a hologram) is then reconstructed to obtain the in-focus particle position, size and shape of every particle (Fugal et al., 2009). The 3-D position of particles in the sample volume can be used to detect particle shattering which appears as a cluster of small particles close to the instrument windows. Under optimum conditions, the smallest particles to be resolved in the whole sample volume must be at least $15 \mu \mathrm{m}$ in size. Particles $>40 \mu \mathrm{m}$ are inspected manually to determine whether they are ice or liquid. During CLACE2013, the background noise level was considerably high, and we need to assume a large number of faulty detections for particles with a maximum dimension of less than $50 \mu \mathrm{m}$. No shattering event was detected in the case study presented in this paper. A digital holographic imager HOLIMO II (Henneberger et al., 2013) was also used to make in-situ image ensembles of cloud particles within a well-defined sample volume that yields single particle size and shadowgraph information for particles between 6 and $250 \mu \mathrm{m}$. Advancements in data processing software now offer phase-resolved size distributions, concentrations, and water contents for cloud particles larger than $20 \mu \mathrm{m}$. Particle phase was determined using a supervised learning algorithm based on two-dimensional shadowgraph water droplets (circular) and ice crystals (non-circular) (Henneberger et al., 2015).

Wind velocity measurements were provided by several sonic anemometers (Metek) and temperature and humidity was provided by Vaisala and Rotronics sensors. Meteorological measurements were also available from the JFJ World Meteorological Organisation (Federal Office of Meteorology and Climatology, Meteo Swiss) weather station at the summit site.

\subsection{Schilthorn}

Schilthorn lies $2970 \mathrm{~m}$ a.s.l. at the summit of the Bernese Alps. The site was selected to act as the upwind measurement location to examine aerosol properties before they arrived at JFJ. Core instrumentation included an Optical Particle Counter (GRIMM Technologies Inc., Model 1.109) for measuring aerosol size distributions over the size range $0.25<D_{\mathrm{p}}<32 \mu \mathrm{m}$.

\section{Data analysis}

The 2D-S component of the 3V-CPI instrument, was used to analyse particle imagery to produce information on the concentration, size and phase of cloud particles. The 2D-S is an optical array probe (OAP) that has two identical orthogonal channels consisting of two laser beams that illuminate horizontal and vertical 128 photodiode arrays with an effective resolution of $10 \mu \mathrm{m}$. Particles passing through either laser shadow the arrays, and images of these particles are built up over sequential time slices (determined by the probes time resolution and the velocity of air sampled through the instrument inlet) over the size range $10<D_{\mathrm{p}}<1280 \mu \mathrm{m}$. The probe was fitted with an anti-shatter knife edge inlet for airborne sampling (Korolev et al., 2011) which helps to minimise any cloud particle shattering, however analysis of interarrival time (IAT) histograms together with probe imagery (Crosier et al., 2011) revealed no characteristic shattered particles and this is likely to be due to the relatively low velocity at which this probe was aspirated throughout the campaign at $\sim 15 \mathrm{~m} \mathrm{~s}^{-1}$.

Discrimination of ice and liquid particles was based on an image circularity criterion (Crosier et al., 2011), and ice water contents (IWCs) were determined with the use of a mass dimensional relationship (Brown and Francis, 1995. The minimum pixel threshold used before discriminating between ice and liquid was 20 pixels, approximately $60 \mu \mathrm{m}$. When using CDP data we found a well defined droplet spectrum $<\sim 35 \mu \mathrm{m}$, while 2D-S and CPI measurements showed no evidence of large drops at JFJ. For this reason we are confident the larger particles identified by the 2D-S are ice crystals. Data from the 2D-S and other imaging probes were analysed using the Optical Array Shadow Imaging Software (OASIS) developed by NCAS in collaboration with Droplet Measurement Technology (www.dropletmeasurement.com). Cloud droplet size distribution measurements were made by several probes in 2013 and 2014 (see instrumentation section). In this paper we primarily report data from the CDP, which detects light scattered by droplets and determines a particle's optical equivalent diameter over the range $2<D_{\mathrm{p}}<50 \mu \mathrm{m}$. Data sets from this probe were provided at 


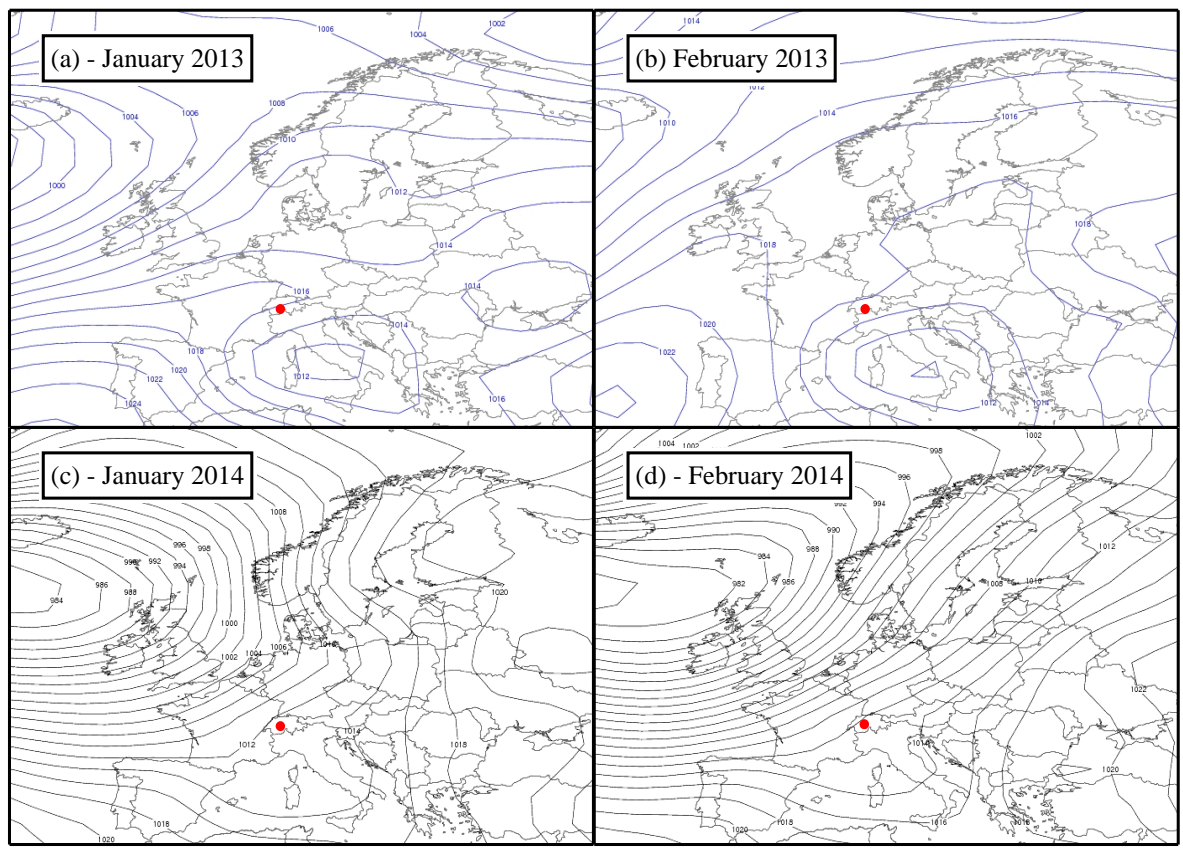

Figure 3. Mean sea level surface pressure charts for Europe during January and February 2013 and 2014. Jungfraujoch, Switzerland labelled (red marker).

$1 \mathrm{~Hz}$ for analysis, and the data were further averaged over $10 \mathrm{~s}$. Reported concentrations refer to the $10 \mathrm{~s}$ averaged data set, with peak values reported for the shorter $1 \mathrm{~s}$ integration periods. Calculation of the ice mass fraction (IMF), critical to identifying transitions between glaciated and liquid cloud, was obtained using information about ice and liquid mass (Eq. 1).

ice mass fraction $=\frac{M_{\text {ice }}}{M_{\text {drop }}+M_{\text {ice }}}$

Where $M_{\text {ice }}$ is the ice mass derived from the 2D-S probe data and $M_{\text {drop }}$ is the liquid water content derived from the CDP. With this information we go further and define glaciated, liquid and mixed-phase cloud periods using threshold values of the IMF. Cloud periods with values $>0.9$ and $<0.1$ were classified as glaciated and liquid cloud, respectively, with anything between these values judged to be mixed-phase in nature. The IMF threshold values applied in this work are described in Korolev et al. (2003).

\section{Campaign overview}

The campaign period during 2013 was often unsettled with a persistent trough across western Europe that lead to northerly wind periods at JFJ dominating for most of the project (Fig. 3a-b). The exception to this were two settled periods, one at the end of January when the Azores high extended its influence across southern Europe and the second at the end of the campaign when a Scandinavian high pressure system de- veloped, blocking the influence of Atlantic cyclones on western Europe. January and February 2014 (Fig. 3c-d) were exceptionally cyclonic, and depressions persistently impacted the Atlantic coastal regions of western Europe. Generally higher pressure over eastern Europe led to these systems stalling and frequently drawing up winds from a southerly direction across central Europe.

Figure 4 shows measured wind direction and velocity at JFJ for both years. The synoptic conditions during 2013 led to prolonged periods of northerly winds, with a low frequency of southerly winds. Conditions during 2014 at the site led to significant periods of strong southerly winds as depressions stalled across western Europe. Wind data from the site showed the direction of these to be almost exclusively from either a northerly $\left(315-045^{\circ}\right)$ or south easterly $\left(115-165^{\circ}\right)$ sector.

\section{Results}

During 2013 and 2014 around 400 cloud events were identified and analysed. The measurement site was determined to be in cloud when $5 \mathrm{~min}$ average LWC measured by the CDP was $>0.01 \mathrm{~g} \mathrm{~m}^{-3}$. The findings from this analysis are described in the following sections.

\subsection{Cloud phase}

Overall the IMF values showed liquid cloud $(\mathrm{IMF}<0.1)$ was present about $10 \%$ of the time in 2013 cases compared 

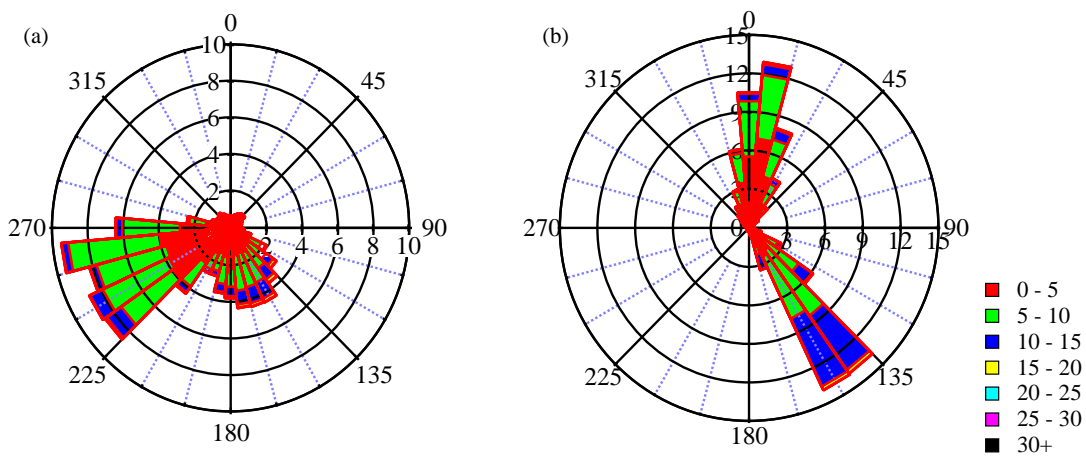

Figure 4. Wind rose showing wind direction frequency (\%) and wind velocity $\left(\mathrm{m} \mathrm{s}^{-1}\right)$ for Jungfraujoch during 2013 (a) and 2014 (b).
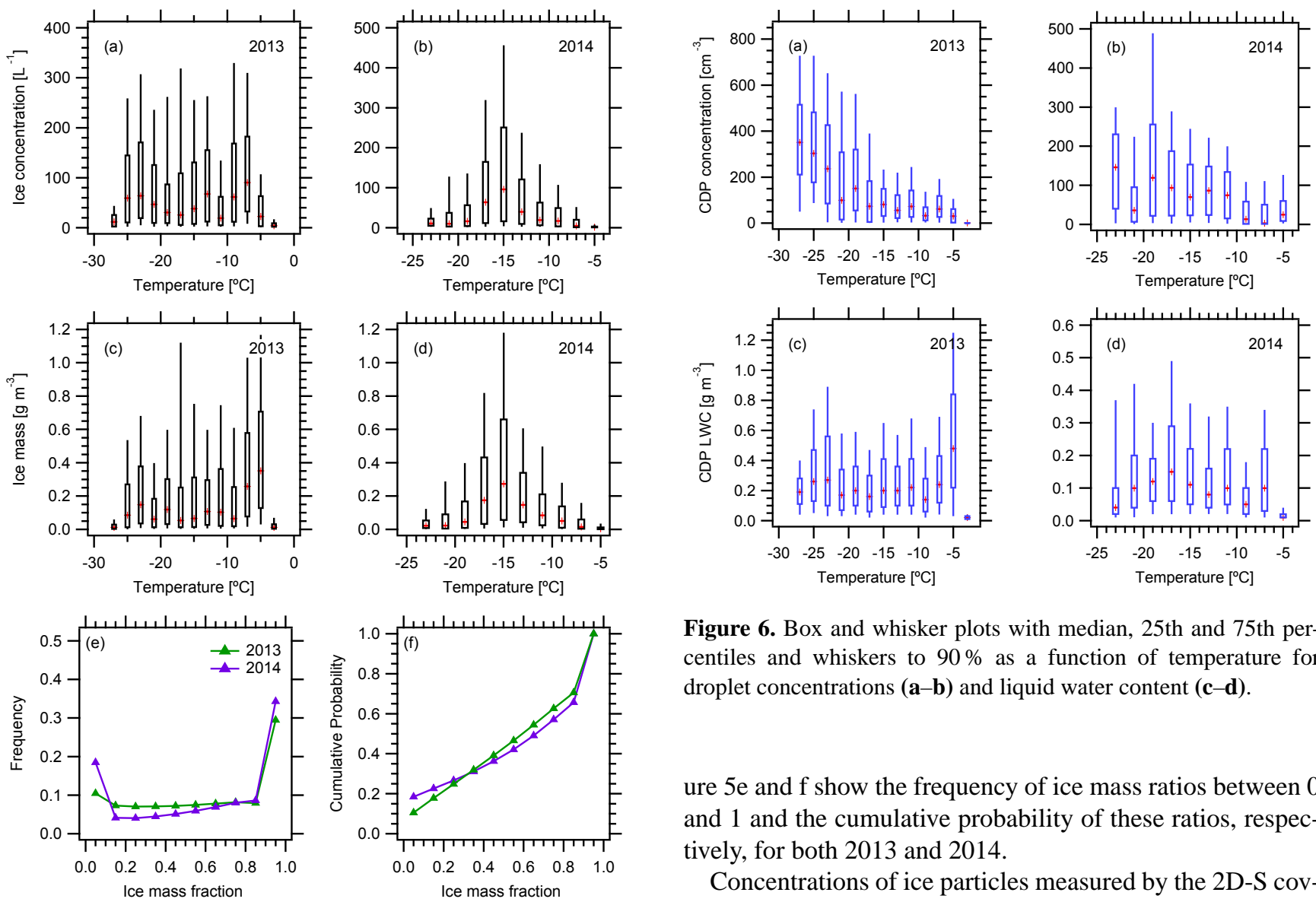

Figure 5. Box and whisker plots with median, 25th and 75th percentiles and whiskers to $90 \%$ as a function of temperature for ice concentrations $(\mathbf{a}-\mathbf{b})$, ice water content $(\mathbf{c}-\mathbf{d})$ and ice mass fraction frequency and cumulative probability for 2013 (green trace) and 2014 (purple trace) (e-f), respectively.

to $18 \%$ during 2014. Glaciated cloud (IMF $>0.9$ ) was observed approximately 34 and $29 \%$ of the time for 2013 and 2014 , respectively. Outside of these periods, cloud was determined to be mixed-phase (IMF between 0.1 and 0.9 ). Fig-
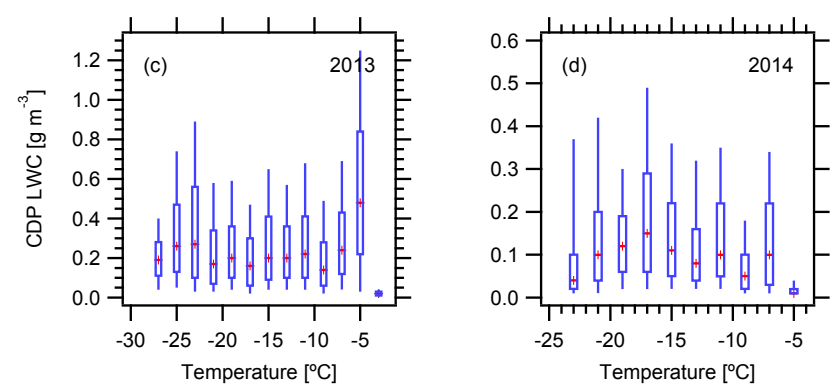

Figure 6. Box and whisker plots with median, 25th and 75th percentiles and whiskers to $90 \%$ as a function of temperature for droplet concentrations (a-b) and liquid water content $(\mathbf{c}-\mathbf{d})$.

ure $5 \mathrm{e}$ and $\mathrm{f}$ show the frequency of ice mass ratios between 0 and 1 and the cumulative probability of these ratios, respectively, for both 2013 and 2014.

Concentrations of ice particles measured by the 2D-S covered a wide range of values during each campaign, with high resolution $1 \mathrm{~Hz}$ data varying from just a few per litre to peak values $>1000 \mathrm{~L}^{-1}$ at times. Percentile plots of ice crystal concentrations during 2014 (Fig. 5b) revealed a relationship with the measured temperature. The highest concentrations of ice were present when temperatures were $\sim-15^{\circ} \mathrm{C}$. During 2013 (Fig. 5a) this pattern was not repeated, and there was no clear association with the ambient temperature. The highest median ice concentrations in both years were around $100 \mathrm{~L}^{-1}$, but in 2014 the concentrations of ice associated with temperatures around $-15^{\circ} \mathrm{C}$ was greater, with the 75th and 90th percentiles reaching $\sim 250$ and $450 \mathrm{~L}^{-1}$, respec- 

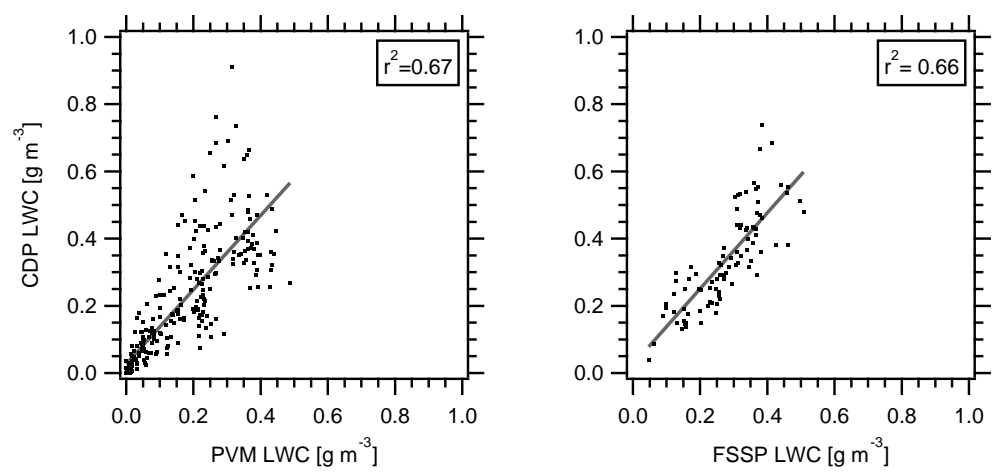

Figure 7. Comparison of measured CDP and PVM LWC values for a cloud event in 2013 (left panel) and CDP compared with an FSSP during a cloud event in 2014 (right panel).

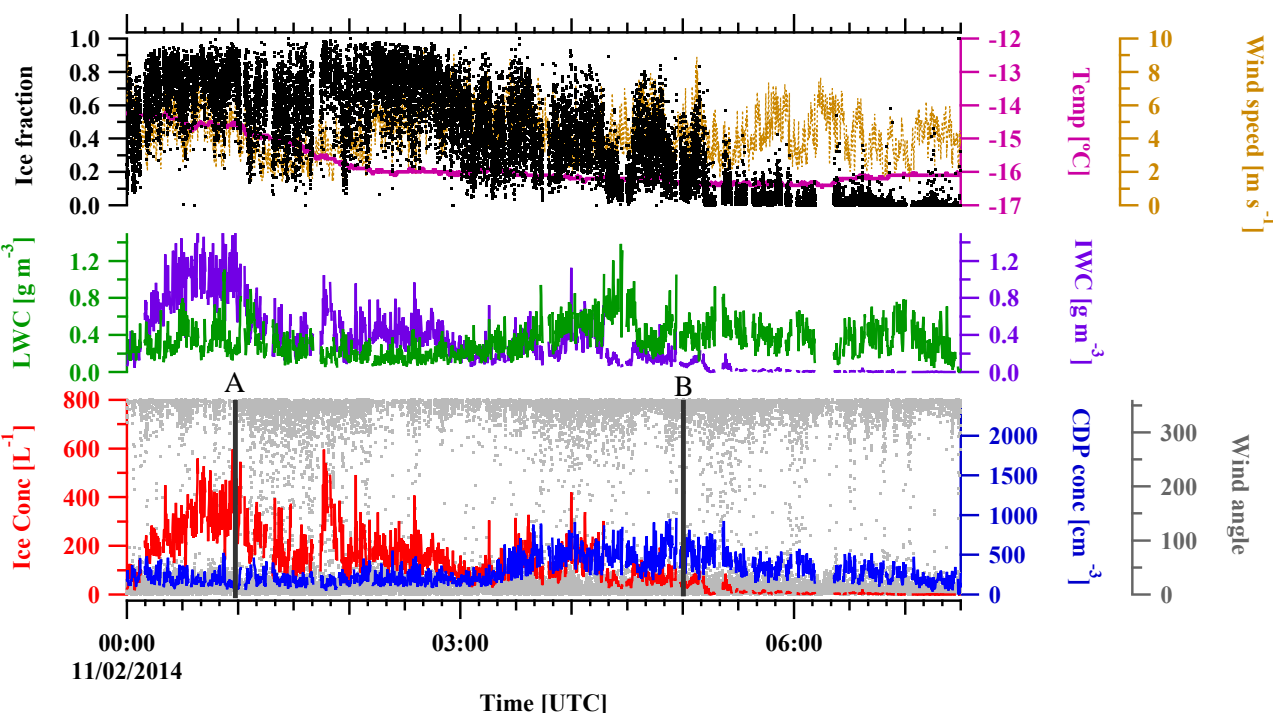

Figure 8. Time series showing an ice mass fraction transition on 11 February 2014. Concentrations from the $2 \mathrm{D}-\mathrm{S}\left(\mathrm{L}^{-1}\right)$ (red trace), liquid droplet concentration from the $\operatorname{CDP}\left(\mathrm{cm}^{-3}\right)$ (blue trace), liquid water content (LWC) from the CDP ( $\mathrm{g} \mathrm{m}^{-3}$ ) (green trace) and ice water content (IWC) from the 2D-S $\left(\mathrm{g} \mathrm{m}^{-3}\right)$ (purple trace), temperature $\left({ }^{\circ} \mathrm{C}\right)$ (magenta trace), wind speed $\left(\mathrm{m} \mathrm{s}^{-1}\right)$ (brown trace) and ice fraction (black trace). Labels A and B mark 5 min 2D-S and CDP size distributions from 00:55 and 05:00 UTC 11 February 2014.

tively, which is about a factor of 2 higher than in 2013. Median ice mass values (Fig. $5 \mathrm{c}$, d) peaked around $0.3 \mathrm{~g} \mathrm{~m}^{-3}$ in both campaigns. In 2014 this maximum was associated with the peak in concentrations around $-15^{\circ} \mathrm{C}$, while in 2013 the highest value was found to be at a higher temperature, around $-8^{\circ} \mathrm{C}$

During 2013 droplet number concentrations (Fig. 6a) were generally between $50-150 \mathrm{~cm}^{-3}$ when the temperature was $>-20^{\circ} \mathrm{C}$, while below this temperature a strong trend to increasing droplet numbers was observed with a peak median value of $350 \mathrm{~cm}^{-3}$ around $-25^{\circ} \mathrm{C}$. This trend was unrelated to changes in the liquid water content (Fig. 6c), suggesting aerosol properties may have been the controlling factor. The highest median liquid water contents were found around $-5^{\circ} \mathrm{C}\left(\sim 0.4 \mathrm{~g} \mathrm{~m}^{-3}\right)$ but were generally around $0.2 \mathrm{~g} \mathrm{~m}^{-3}$. In 2014 median LWCs (Fig. 6d) were $\sim 0.2 \mathrm{~g} \mathrm{~m}^{-3}$, about a fac- tor of 2 less than those measured in 2013. Generally higher droplet number concentrations (Fig. 6c) were again observed at lower temperatures (peak median value $\sim 150 \mathrm{~cm}^{-3}$ ). During the 2013 campaign comparison of the CDP and the PVM (Fig. 7a) showed good agreement for a cloud period lasting almost $24 \mathrm{~h}$. In 2014 the PVM was not available, however the CDP compared well with an FSSP (Fig. 7b) over the time period represented in Fig. 8.

\subsection{Cloud microphysics and ice mass fraction transitions}

Frequent transitions in the IMF fraction were observed during cloud events. These transitions were observed over different temporal scales varying from hours to just seconds. Figure 8 shows a cloud event that changed over several hours 

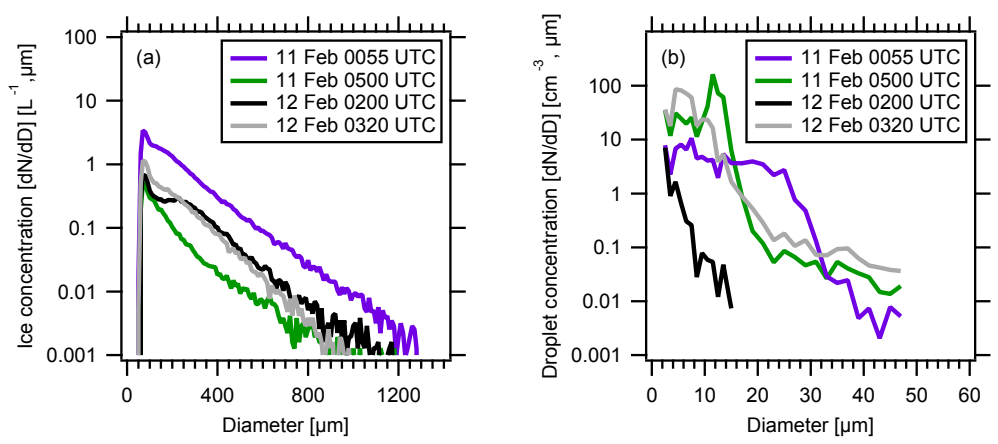

Figure 9. Size distributions during an ice fraction transition period on 11 (Fig. 7) and 12 (Not Shown) February for ice particles measured by the 2D-S (a) and liquid droplets measured by the CDP (b).

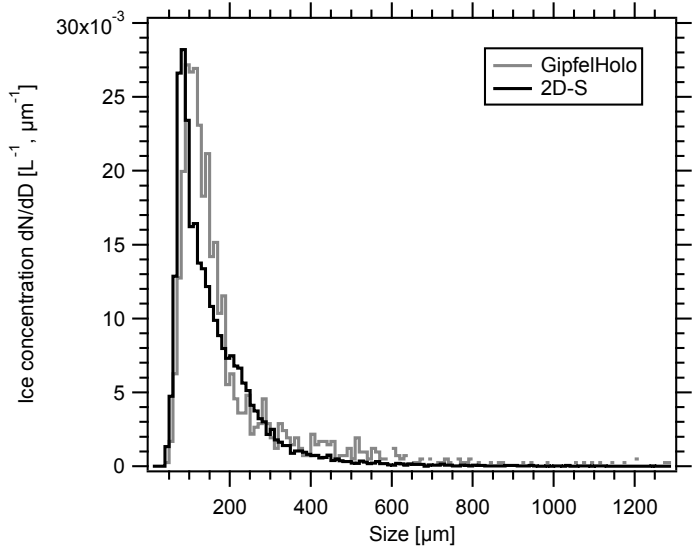

Figure 10. Ice particle size distributions from the GipfelHolo (grey trace) and 2D-S (black trace).

to be predominantly liquid after having been mixed with high IMF values. Ice and liquid particle size distributions (PSDs) for high and low IMF periods (marked A and B in Fig. 8) can be found in Fig. 9. Generally a dominant peak in the ice PSDs was centred around $100 \mu \mathrm{m}$, with a second mode sometimes evident around $200 \mu \mathrm{m}$. Comparison of 2D-S size distributions with those measured by the Gipfelholo (Fig. 10) over a $\sim 90$ min period also reveals the presence of small ice crystals. PSDs from the CDP (Fig. 9) showed that low IMF values were associated with increases in the number of droplets $<\sim 20 \mu \mathrm{m}$.

Figure 11 shows rapid fluctuations sometimes seen at this site where variation in the IMF between glaciated and liquid conditions takes place over short time scales of $\sim 1 \mathrm{~s}$. Images from the 2D-S and CPI (Fig. 12) show small pockets of ice crystals absent of liquid droplets. IMFs $>0.9$ and often $=1$ were observed during these periods. In other cloud events, IMFs would often cycle between higher and lower values several times over several hours. One such period was observed during the 2013 campaign (Fig. 13).

\subsection{Ice nuclei concentration predictions}

At the Schilthorn site during the 2014 campaign we used measurements of aerosol size distributions from the GRIMM instrument as input to the primary ice nucleation parameterization developed by DeMott et al. (2010) (hereafter referred to as D10). This scheme was based on data collected from nine airborne measurement campaigns of IN using a continuous flow diffusion chamber, from different locations around the world over the temperature range -9 to $-36^{\circ} \mathrm{C}$ and where saturation with respect to water was $>100 \%$. An additional constraint was to use data only where aerosol size distribution measurements were also available. They provided a parameterization based on both the number of aerosol particles $>0.5 \mu \mathrm{m}$ diameter and temperature. They showed that $62 \%$ of the observed IN concentrations could be predicted to within a factor of 2 with this approach, although they highlighted the need for further geospatial data sets to test and improve the parameterization.

Aerosol data for use with D10 were selected only during periods at Schilthorn where the measured relative humidity (RH) was $<80 \%$. This was to reduce artefacts in the aerosol data caused by sampling during possible in-cloud periods. The maximum particle diameter measured and used in the D10 data sets was $1.6 \mu \mathrm{m}$ and for this reason the same upper size limit was applied to the Schilthorn sampled particle concentrations, and so the same size range, i.e. $0.5<D<1.6 \mu \mathrm{m}$, was used for input to test the scheme. The parameterization (Eq. 2) was used to predict IN concentrations at JFJ based on aerosol properties at Schilthorn. The parameterization is represented as follows:

$n_{\mathrm{IN}, T_{\mathrm{k}}}=a\left(273.16-T_{\mathrm{k}}\right)^{b}\left(n_{\mathrm{aer}, 0.5)}{ }^{\left(c\left(273.16-T_{\mathrm{k}}\right)+d\right)}\right.$,

where $a=0.0000594, b=3.33, c=0.0264, d=0.0033$, $T_{\mathrm{k}}$ is the cloud temperature in degrees Kelvin, $n_{\mathrm{aer}, 0.5}$ is the number concentration of aerosol particles $>0.5 \mu \mathrm{m}$ and $n_{\mathrm{IN}, T_{\mathrm{k}}}$ is the ice nuclei number concentration $\left(\mathrm{L}^{-1}\right)$ at $T_{\mathrm{k}}$.

The Schilthorn and JFJ sites are approximately $11 \mathrm{~km}$ apart at altitudes of 2970 and 3580 ma.s.l., respectively. Changes in wind speed at each site showed a generally 


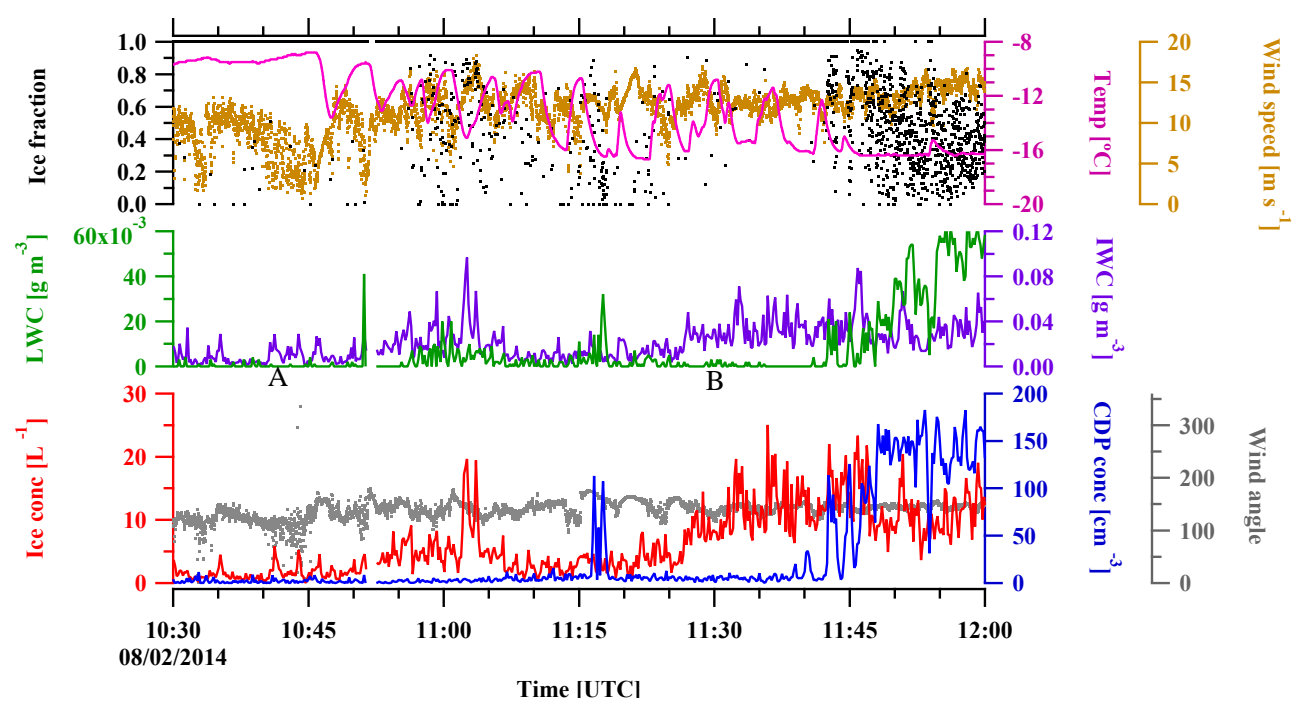

Figure 11. Time series from a period of swift ice fraction transitions on 8 February 2014 for ice number concentration from the $2 \mathrm{D}-\mathrm{S}\left(\mathrm{L}^{-1}\right)$ (red trace), liquid droplet concentration from the $\mathrm{CDP}\left(\mathrm{cm}^{-3}\right)$ (blue trace), liquid water content (LWC) from the CDP $\left(\mathrm{g} \mathrm{m}^{-3}\right)(\mathrm{green}$ trace) and ice water content (IWC) from the 2D-S $\left(\mathrm{g} \mathrm{m}^{-3}\right)$ (purple trace), temperature $\left({ }^{\circ} \mathrm{C}\right.$ ) (magenta trace), wind speed ( $\mathrm{m} \mathrm{s}^{-1}$ ) (brown trace), wind angle $\left(^{\circ}\right)$ (grey trace) and ice fraction (black trace).

good correlation, and based on this good connectivity with both sites, the influence of the same air mass has been assumed. When ice crystal concentrations, $N_{\text {ice }}$, observed at JFJ (Fig. 14) are compared with the D10 prediction observed values are seen to be under-predicted by as much as $2-3$ orders of magnitude.

\section{Discussion}

\subsection{Cloud microphysics}

Measurements of cloud microphysical structure at JFJ during the 2013 and 2014 periods revealed frequent variation in the liquid and ice phases of the cloud as evident in the calculated IMFs. Figure 5e shows the frequency of calculated IMF values at JFJ, indicating that mixed-phase clouds dominated the microphysics at JFJ, with significant contributions from liquid (10 and $18 \%$ for 2013 and 2014, respectively) and fully glaciated clouds (29 and 34\% for 2013 and 2014, respectively). Korolev et al. (2003) investigated the characteristics of mixed-phase clouds associated with frontal systems from aircraft data collected during several projects that took place in Canada, finding the frequency of liquid and glaciated clouds to be $\sim 26$ and $\sim 38 \%$, respectively, over a similar temperature range.

Changes in IMF values were found to occur over different temporal scales (Figs. 8, 11 and 13) and generally in the absence of changes in ambient conditions such as wind speed, direction and temperature. During both campaigns a number of changes in the mass of ice and liquid phases led to changes in the IMF. For example, increasing IMF values were observed under the following conditions:

1. constant LWC and increasing IWC

2. decreasing LWC and increasing IWC

3. decreasing LWC and constant IWC

4. where the increases in IWC were greater than the increases in LWC.

Periods of decreasing IMFs were associated with

1. constant IWC and increasing LWC

2. increasing LWC and decreasing IWC

3. increasing LWC and constant IWC

4. periods where the increases in LWC were greater than increases in IWC.

It is important to recognise the range of conditions that led to changes in the ice mass fraction and how these relate to the processes driving each IMF transition. Changes in the LWC are likely to be related to the depth of cloud, cloud base altitude and ambient temperature. The source of changes in IWC values are discussed in the following sections.

When ice was present, peak concentrations reached values $>1000 \mathrm{~L}^{-1}$ at times. When using D10, predicted IN values were found to be significantly fewer (sometimes by 3 orders of magnitude) than the concentrations of ice measured at JFJ. Measurements made in previous campaigns of IN activity at this site were also unable to explain the high concentrations of ice (Chou et al., 2011). 


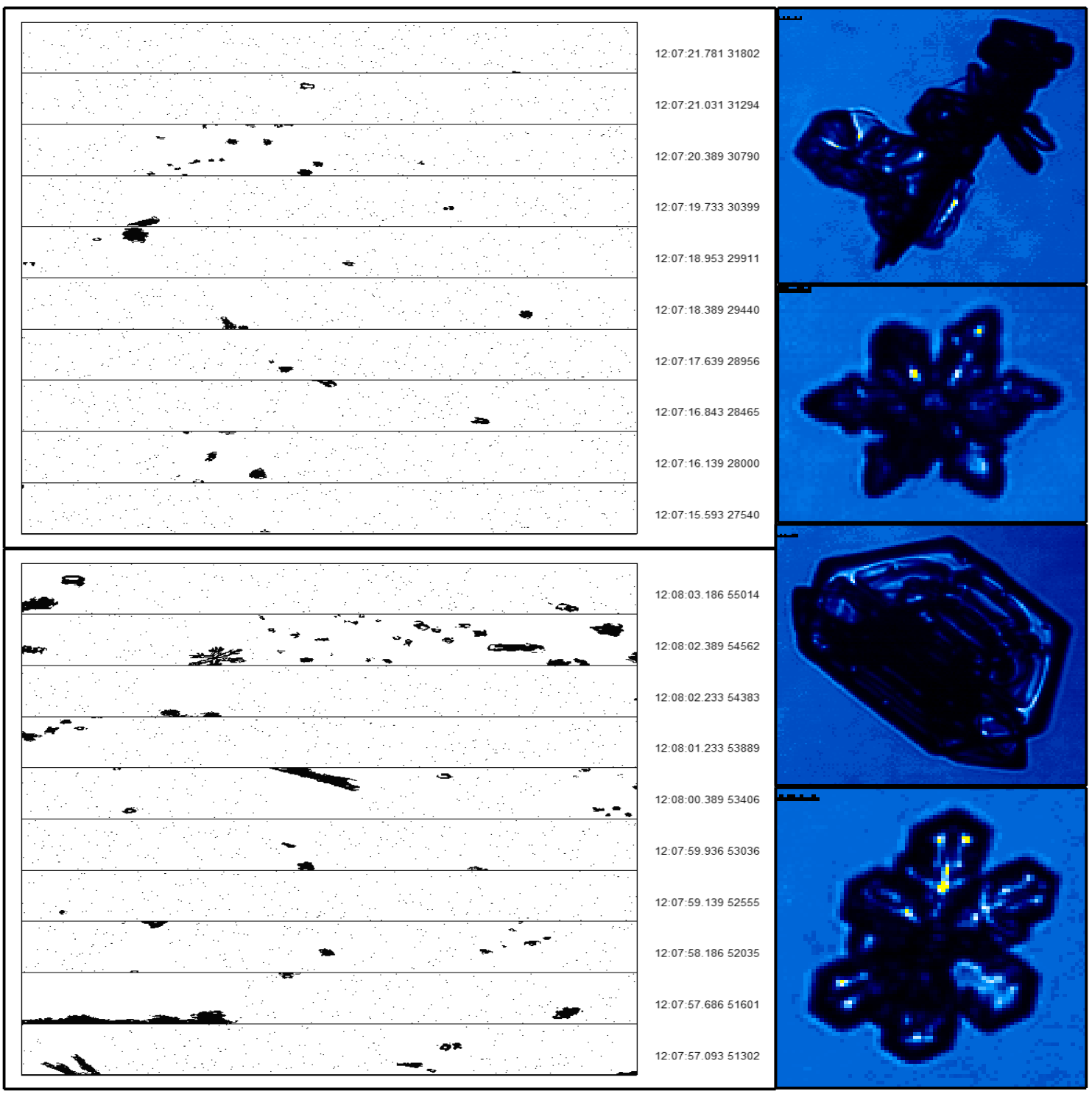

Figure 12. Examples of 2D-S imagery showing swift transitions (left) between liquid, mixed-phase and glaciated cloud and CPI photographs of ice crystals from around the same time on 8 February 2014.

A powerful secondary ice production mechanism, the Hallett-Mossop (H-M) process (Hallett and Mossop, $1974)$ is known to operate over the temperature range $-3^{\circ} \mathrm{C}<T<-8^{\circ} \mathrm{C}$, the so-called $\mathrm{H}-\mathrm{M}$ zone. This can lead to significant enhancements in the number of ice particles above what would be expected through heterogeneous ice formation alone. However, temperatures at JFJ were generally colder than in the $\mathrm{H}-\mathrm{M}$ zone, and ice concentrations as a function of temperature (Fig. 5a-b) did not show any significant increase at higher temperatures.

During 2014 a maximum in ice concentrations was observed at a temperature of $\sim-15^{\circ} \mathrm{C}$. Secondary ice production through the breakup of fragile airborne ice crystals that sometimes form at this temperature has been observed in the laboratory (Vardimen, 1978; Griggs and Choularton, 1986), and others have suggested ice-ice collisions as a source of secondary ice in natural clouds (Rangno and Hobbs, 2001). Recent airborne studies in natural clouds have found little evidence for this process, e.g. Lloyd et al. (2014, 2015) and Crosier et al. (2011) in layer clouds and Crawford et al. (2012) in convective clouds. However, while Yano and Phillips (2011) concluded that H-M is the dominant secondary ice production process in clouds that span the required temperature range, in colder clouds mechanical breakup dominates the overall number concentrations, with a peak rate of production around $-15^{\circ} \mathrm{C}$. Despite the maximum observed in ice concentrations around this same temperature in 2014 , we generally did not observe the fragile 


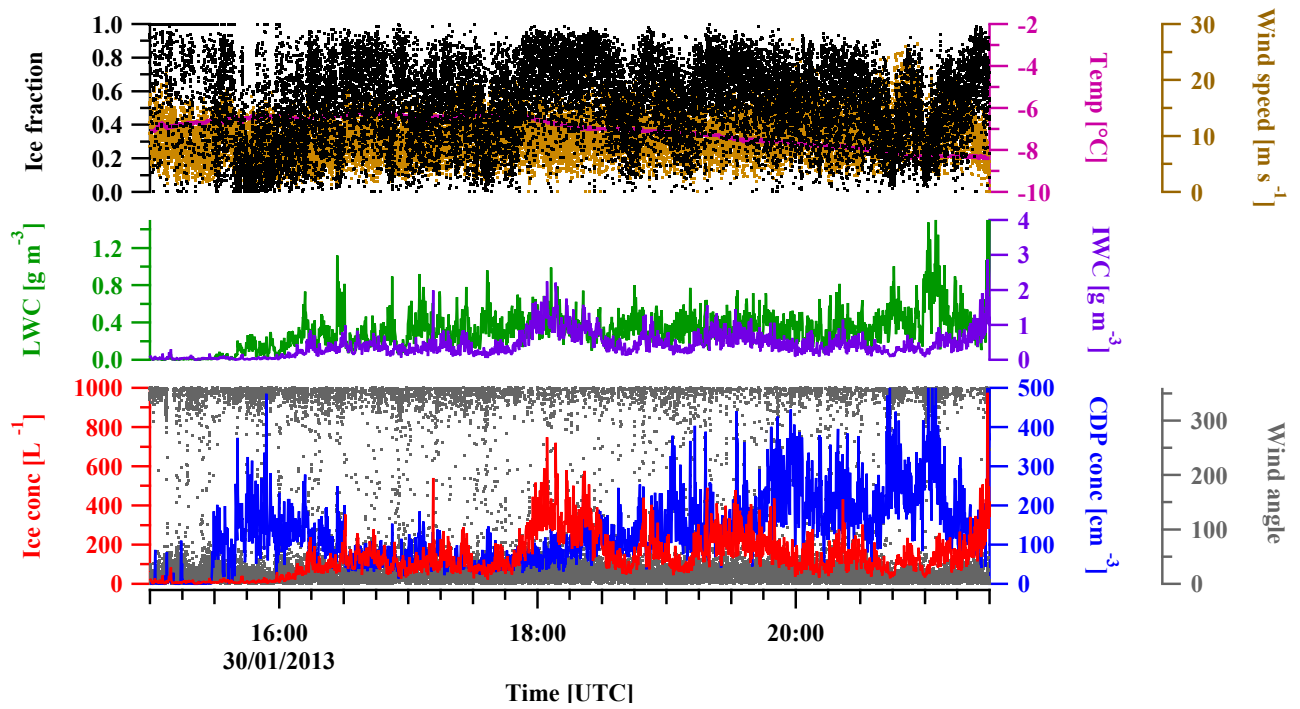

Figure 13. Time series showing changes in ice mass fractions on 30 January 2013 for ice number concentration from the $2 \mathrm{D}-\mathrm{S}\left(\mathrm{L}^{-1}\right)($ red trace), liquid droplet concentration from the CDP $\left(\mathrm{cm}^{-3}\right)$ (blue trace), liquid water content (LWC) from the CDP ( $\left.\mathrm{g} \mathrm{m}^{-3}\right)(\mathrm{green}$ trace) and ice water content (IWC) from the 2D-S $\left(\mathrm{g} \mathrm{m}^{-3}\right)$ (purple trace), temperature $\left({ }^{\circ} \mathrm{C}\right)$ (magenta trace), wind speed ( $\left.\mathrm{m} \mathrm{s}^{-1}\right)($ brown trace), wind angle $\left(^{\circ}\right)$ (grey trace) and ice fraction (black trace).

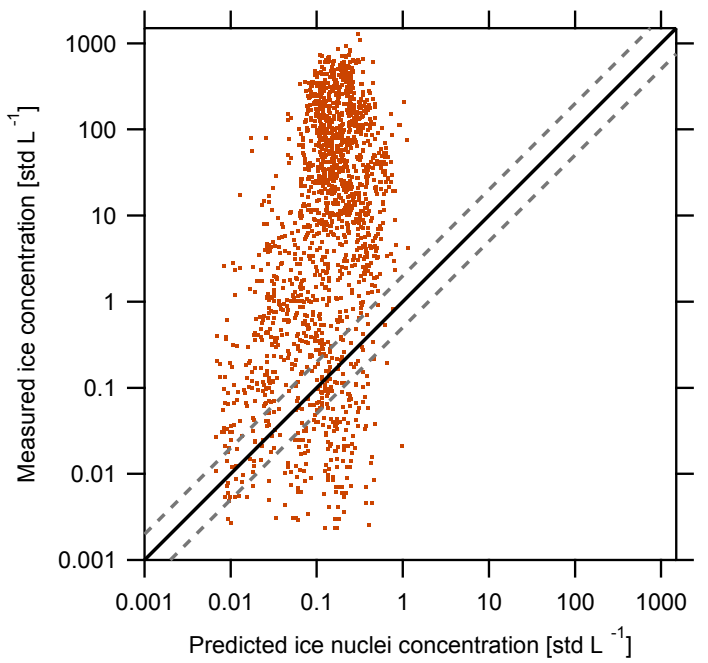

Figure 14. Comparison between the measured number of ice particles by the 2D-S and the predicted ice nuclei concentration using the DeMott et al. (2010) parameterisation. The solid black line represents a $1: 1$ fit, and dashed grey lines represent a factor of 2 from this line.

dendritic ice typically associated with this process. Imagery from the CPI showed sectored plates and irregular shapes to be the dominant habit. Figure 15 shows some of the typical crystal habits that were observed when temperatures were $\sim-15^{\circ} \mathrm{C}$. Whilst this process cannot be ruled out and further investigation is required, there is currently no evidence in the literature that this mechanism would be capable of producing the ice crystals concentrations observed.
Rangno (2008) highlighted an alternative secondary ice process, finding that fragmentation of freezing drops could contribute up to $5 \%$ to the total ice concentration in shallow stratiform clouds. There was no evidence of this taking place at JFJ and the process is not thought to be powerful enough to explain the very high number of ice particles observed at JFJ.

\subsection{Blowing snow}

At JFJ there is the potential for clouds affecting the site to be in contact with large areas of snow-covered mountain surfaces. Rogers and Vali (1987) made measurements at the Elk Mountain Observatory, Wyoming ( $3400 \mathrm{~m}$ a.s.1.), finding the cloud close to the ground to be influenced by high concentrations (up to $\sim 1000 \mathrm{~L}$ ) of small ice crystals that appeared to be generated at the surface. Aircraft measurements around $1 \mathrm{~km}$ above Elk mountain found that ice concentrations were around 2 orders of magnitude lower than those close to the surface. When investigating the link between ice concentrations and wind speed they found no strong indication of a relationship suggestive of snow re-suspension. Vali et al. (2012) used the Wyoming Cloud Radar (WCR) on the Wyoming King Air aircraft to analyse ground layer snow clouds (GSCs) over the Medicine Bow Mountains of southeast Wyoming and over the Sierra Nevada. They found plumes of ice crystals originating from the surface, with strong radar reflectivity in a layer up to around $200 \mathrm{~m}$ above the ground that gradually decreased with height. On occasion these GSCs were seen to extend up to $1 \mathrm{~km}$ in altitude. Lachlan-Cope et al. (2001) also found that cloud layers in contact with the ground over the Avery Plateau on the 


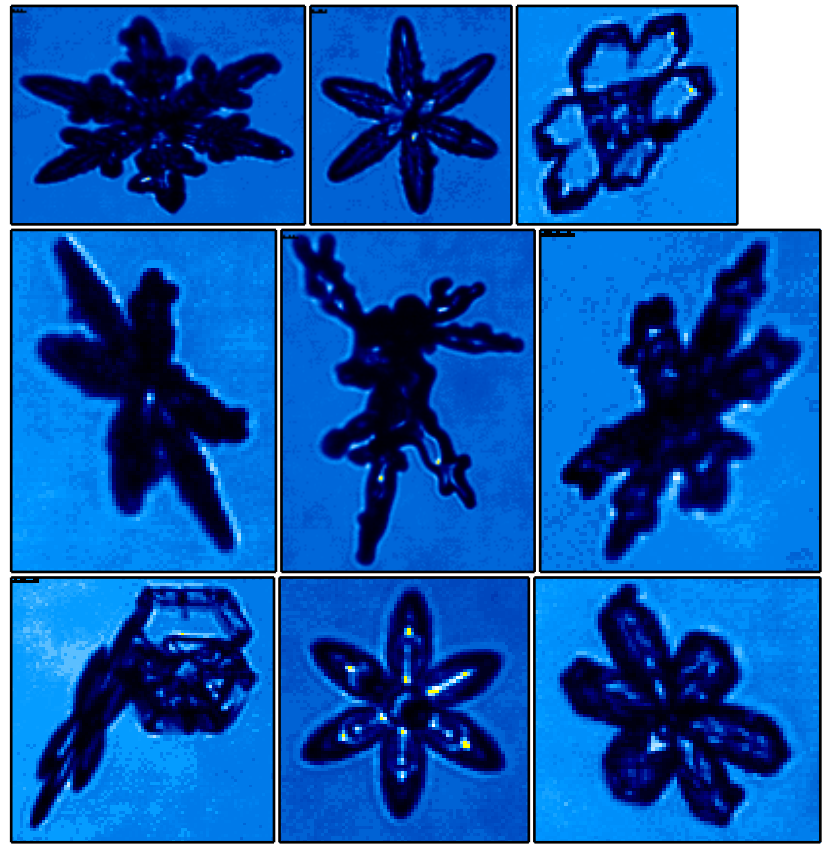

Figure 15. Examples of typical ice particles photographed by the $\mathrm{CPI}$ instrument at temperatures around $-15^{\circ} \mathrm{C}$.

Antarctic Peninsula contained higher concentrations (up to $\sim 250 \mathrm{~L}^{-1}$ ) of ice than would be expected to form through primary heterogeneous ice nucleation. They concluded that very small $(<5 \mu \mathrm{m})$ blown snow particles could have seeded these clouds. Baumgardner et al. (2014) also made mountaintop measurements finding that despite the temperatures only just below freezing, a significant fraction of particles measured by a Cloud Particle Spectrometer with Polarization Detection (CPSPD) were ice. The depolarisation information from this instrument also suggested aspherical particles that indicate ice were most evident $>\sim 40 \mu \mathrm{m}$ with a clear droplet spectrum at the smaller sizes, which is consistent with observations at JFJ.

During both JFJ campaigns the association of ice particle concentrations and wind velocity was investigated for each cloud event. In around $27 \%$ of 2013 and $13 \%$ of 2014 cases the relationship between the ice number concentration and wind velocity was found to be significant at the $99 \%$ confidence level. Despite this finding many of these events displayed low correlation coefficients, although in a few cases, there was a much stronger relationship. Figure 16a-d shows scatter plots of $10 \mathrm{~s}$ mean ice number concentration vs. wind velocity, where it was identified that blowing snow was contributing to the ice number concentrations at JFJ. Cloud event 110 (Fig. 16c) was the most significant blowing snow event identified during both campaigns, with a $r^{2}$ of 0.45 . This event was detected shortly after a significant snowfall event, with accumulations of $29 \mathrm{~cm}$ measured at a site in the JFJ region, Männlichen. Figure $16 \mathrm{c}-\mathrm{d}$ shows that during cloud events with a more evident association with wind speed, ice number concentrations are generally only a few tens per litre. Other cases (Fig. 16a-b) with lower $r^{2}$ values represent events where blowing snow is making some contribution, but other ice formation processes appear to be dominant, leading to much higher concentrations of ice. In the majority of cloud events however no significant contribution from blowing snow could be identified, examples of which can be found in Fig. 17. Measurements of blowing snow have found that for resuspension of snow particles from the surface into the atmosphere, the wind speed must be above a threshold value of $\sim 5 \mathrm{~m} \mathrm{~s}^{-1}$ (Mahesh et al., 2003; Gordon and Taylor, 2009). During the strongest blowing snow events observed at JFJ (Fig. 16c-d) this threshold value is evident, with typically low ice number concentrations at low wind speeds quickly increasing as the wind velocity rises above $\sim 5 \mathrm{~m} \mathrm{~s}^{-1}$.

Ice particle size distributions (PSDs) (Figs. 16e-h and $17 \mathrm{e}-\mathrm{h})$ exhibited a significant peak in size around $80 \mu \mathrm{m}$ (confirmed by multiple instruments including holographic imagery; Schlenczek et al., 2015) regardless of whether blowing snow was contributing to the cloud or not. Rogers and Vali (1987) also presented PSDs that are consistent with the findings here, namely a peak in concentrations at sizes $<100 \mu \mathrm{m}$ that appear to occur independently of wind speed. Good agreement was found between the 2D-S and a separate instrument, the HOLIMO II (Fig. 18), which also showed concentrations of ice that were unrelated to the wind velocity. The lack of a relationship between the number of ice particles measured at JFJ and the wind speed suggests an alternative source for the anomalously high concentrations of ice observed at this site. The discussion below focuses on some of the various possible mechanisms which may explain this. In particular, we examine possible local surface sources and the different mechanisms that may lead to the observed ice concentration enhancements.

\subsection{Pre-activated aerosol}

A possible source of enhanced ice concentrations from the surface could be due to the availability of "pre-activated" aerosol particles. These are particles that have already acted as an IN, or have been scavenged by growing ice crystals or were simply exposed to a temperature lower than $\sim 235 \mathrm{~K}$. Wagner et al. (2014) investigated aerosol particles before and after pre-activation in the AIDA cloud chamber and showed that the IN efficiency of these particles increased as a result. Ice on the surface of the surrounding mountains and glaciers at JFJ will be sublime in conditions when saturation with respect to ice is $<1$. This may lead to the presence of pre-activated particles on the surface, and it is possible that these can then be resuspended by wind into the cloud in contact with the surface, leading to an increased flux of IN and leading to an enhancement in the number of ice particles observed. No measurements have been made of aerosol fluxes from such a cloud enveloped snow surface, however, the flux 

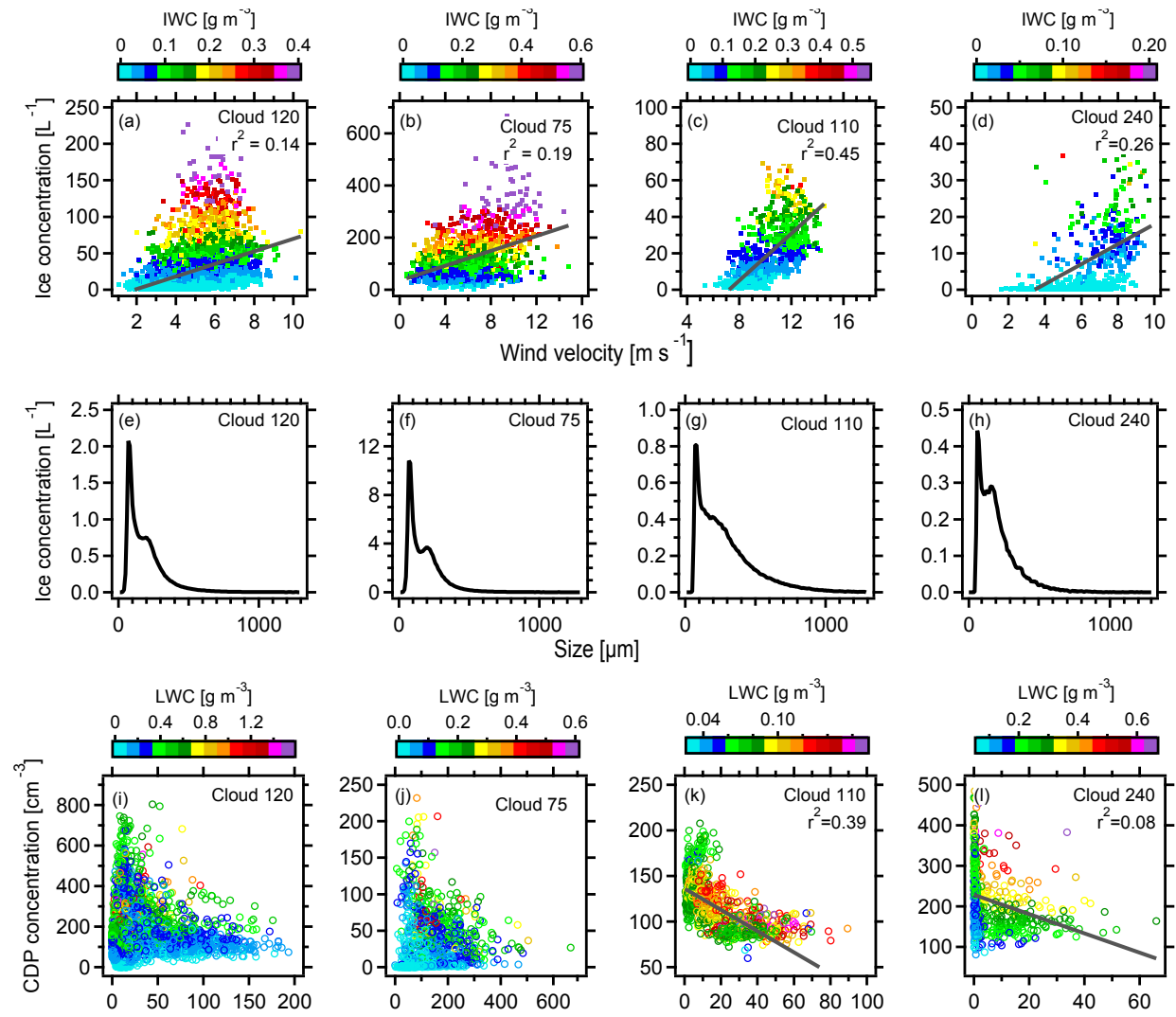

Ice concentration $\left[\mathrm{L}^{-1}\right]$

Figure 16. Scatter plots for ice concentration vs. wind speed, coloured as a function of ice water content (a-d). Droplet number concentrations vs. ice concentration, coloured as a function of liquid water content (i-l), and ice particle size distributions for each blowing snow event (black trace) with cumulative frequency (grey trace and shaded area) $(\mathbf{e}-\mathbf{h})$.
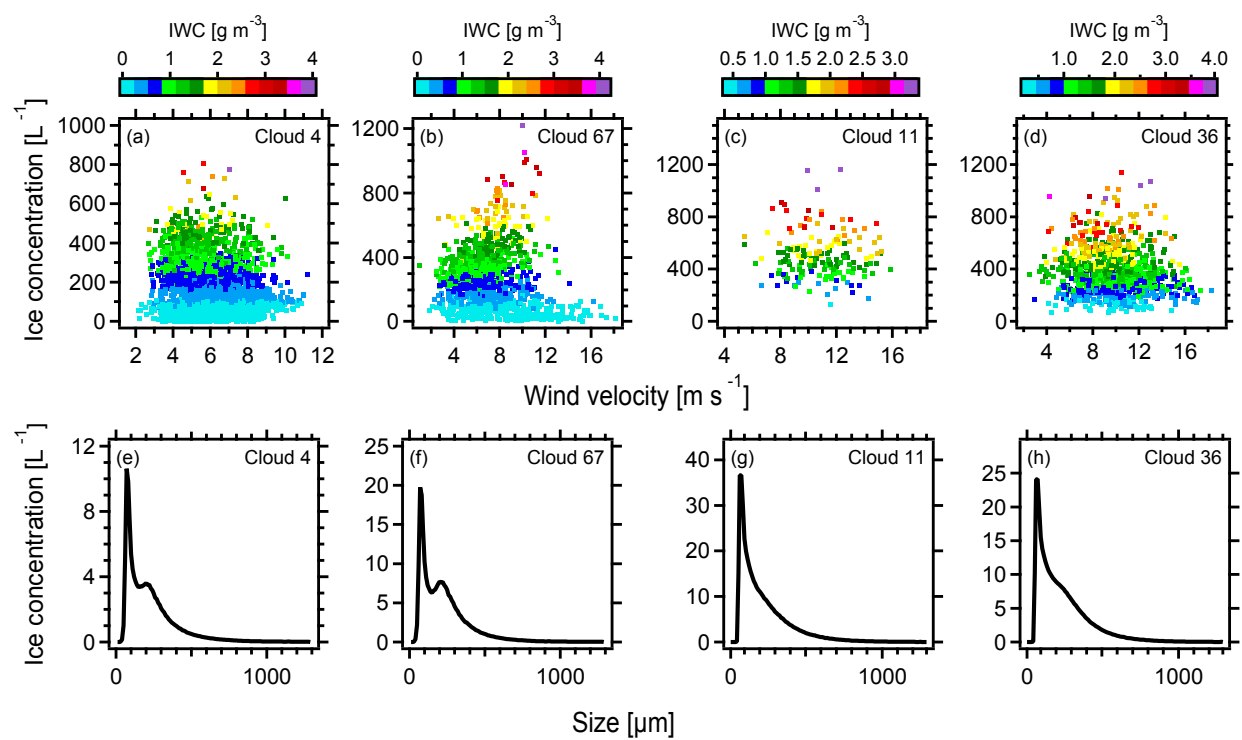

Figure 17. Scatter plots for ice concentration vs. wind speed, coloured as a function of ice water content (a-d), and ice particle size distributions for each non-blowing snow event (black trace) with cumulative frequency (grey trace and shaded area) (e-h). 


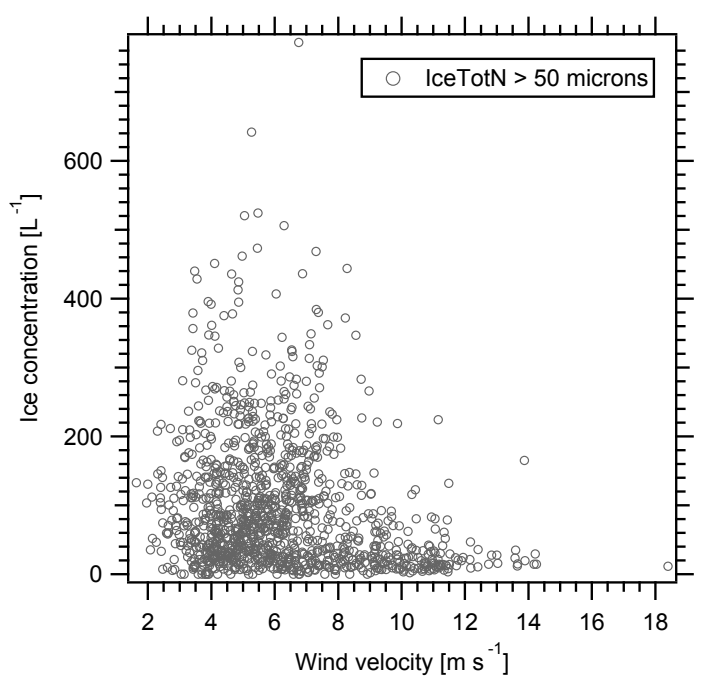

Figure 18. Scatter plot of ice concentration from the HOLIMO II vs. wind velocity.

of aerosols associated with this process may not be as sensitive to wind speed as the flux due to blowing snow. Therefore this mechanism could be consistent with the data presented and could operate alongside the emission of ice crystals from hoar frost deposits discussed below.

\subsection{Riming on mountain surfaces}

Rogers and Vali (1987) could not rule out riming being responsible for the ice concentrations they observed due to the volume of riming events that take place on mountain surfaces. Supercooled water droplets will be deposited to the surface by turbulent diffusion at rates according to their size and the surface micrometeorological characteristics such as roughness length (e.g. Gallagher et al., 1988). On deposition to a snow surface, these droplets will freeze quickly and this may be a low level source of small ice splinters. Generally this mechanism is not consistent with the data gathered as we see no evidence of a link between the number of small ice crystals and either the number of droplets or the cloud liquid water content for much of the campaign.

\subsection{Growth and detachment of vapour grown surface ice or "hoar frost"}

It is well known (see for example Xu et al., 2013, and references therein) that frost flowers forming on recently formed sea ice in the Arctic and Antarctic regions are an important source of atmospheric aerosol. It is envisaged that these frost flowers, which contain high concentrations of dissolved salt fragments, evaporate leaving behind suspended residues that form atmospheric aerosol (Perovich and Richter-Menge, 1994; Rankin et al., 2000). Substantial fluxes of these aerosol (of order $10^{6}$ particles $\mathrm{m}^{-2} \mathrm{~s}^{-1}$ ) are estimated at wind speeds as low as $1 \mathrm{~m} \mathrm{~s}^{-1}$. It is well known that vapour grown ice crystals form on the crystalline surface of lying snow, sometimes referred to as "surface hoar". These crystals equivalent to frost flowers are often observed at a higher number density than the sea-ice ice frost flowers, Gallett et al. (2014). Unfortunately, no measurements have been made of surface frost crustal densities on alpine snow cover or possible ice fluxes from them due to fragmentation. Nevertheless it can readily be estimated that a particle flux of this order could give rise to concentrations of a several hundred to 1000 crystals per litre, comparable to those observed. The mechanism of formation on snow surfaces is rather different to sea ice or lake ice frost flowers and is generally referred to as hoar frost or white frost, although definitions vary and frost flower is often used synonymously. When a snow surface is enveloped by a super-cooled liquid water or mixed-phase cloud at near water saturation then hoar frost crystals on the snow surface will grow by vapour diffusion. If these crystals are then detached from the surface due to mechanical fracture they are likely to contribute substantially to the ice crystal population within the cloud. If surface production rates of ice crystals are similar to those reported by Xu et al. (2013) for aerosol particles, then we postulate that these may be capable of explaining the high concentrations of ice crystals observed near the surface at the summit of JFJ. Due to the fragility of the "frost" crystals, often composed of needle habits or interlocking needles, relatively small variations in turbulence at the surface could cause their fragmentation and removal.

Overall the current evidence points to a surface based secondary ice particle production process which is most effective near the summit (producing large numbers of small ice particles observed). The numbers of ice crystals far exceed the number of ice nuclei predicted, e.g. by D10, often by many orders of magnitude and are similarly greater than ice nuclei concentrations measured previously under any conditions. The most likely source would seem to be splinters produced by the break-up of frail frost ice crystals on the surface. There is also a contribution from blowing snow in strong winds, although the process does not appear to be powerful enough to produce the very high concentrations of ice observed at JFJ and also can't explain the presence of these high concentrations that are measured below the wind speed threshold for blowing snow.

\section{Conclusions}

Observations of cloud microphysical structures and their association with aerosol properties have been presented from a measurement campaign that took place at Jungfraujoch and Schilthorn, Switzerland.

- The fraction of liquid cloud during 2013 and 2014 was found to be 10 and $18 \%$, respectively. During 2013 totally glaciated cloud was observed $30 \%$ of the time, with a slight increase in incidence to $34 \%$ in 2014 . 
These findings suggest mixed-phase clouds dominate the cloud microphysics at Jungfraujoch.

- Changes in the LWC and IWC lead to significant changes in ice mass fraction values occurring over temporal scales of seconds to hours during both 2013 and 2014.

- Calculated cloud ice mass fraction values at Jungfraujoch are influenced by a number of often competing changes in cloud microphysical properties involving the ice and liquid phases, where changes in the different phase loadings were often independent of one another.

- 400 cloud events were observed during the campaigns, with ice number concentrations varying from zero during liquid dominated cloud periods to over $1000 \mathrm{~L}^{-1}$ during mixed-phase and glaciated cloud periods.

- Secondary ice production through the $\mathrm{H}-\mathrm{M}$ process, mechanical breakup of fragile ice through in-cloud collisions and the fragmentation of freezing drops does not appear to be capable of explaining the very high concentrations of ice crystals observed at JFJ.

- Using aerosol measurements from the Schilthorn site as input, the DeMott et al. (2010) primary ice nucleation scheme, could not account for the anomalously high concentrations of ice particles observed at Jungfraujoch. This is consistent with previous IN measurements at JFJ (Chou et al., 2011).

- Blowing snow was found to make a small contribution to about 27 and $13 \%$ of cloud events in 2013 and 2014, respectively. The events with the strongest correlation coefficients between wind speed and ice crystal concentrations produced concentrations of ice that were generally $<\sim 100 \mathrm{~L}^{-1}$.

- Ice crystals were found to be generally small $(<300 \mu \mathrm{m})$, with bi-modality sometimes evident in the size distributions, with modes centred around $80 \mu \mathrm{m}$ and another at $200 \mu \mathrm{m}$, confirmed by multiple cloud instruments.

- Despite high concentrations of small ice particles and bi-modal inter-arrival-time (IAT) histograms, breakup on probe inlets is not thought to be the source of these high concentrations of ice; there is no evidence of crystal shattering in the probe imagery.

- Evidence presented supports the hypothesis that the snow-covered surfaces around the JFJ area a major source of cloud ice particles. The contributions of windblown snow, pre-activated aerosol, surface based rimesplintering and breakup of vapour grown ice, including frost on the surface have all been considered as potential sources of cloud ice at the site.
- Blowing snow has been shown to contribute to the ice number concentration at times when this concentration is low $\left(<\sim 100 \mathrm{~L}^{-1}\right)$, but it is not an explanation for the number of ice particles that are observed in the high to very high concentration events $>100 \mathrm{~L}^{-1}$ (and sometimes $>1000 \mathrm{~L}^{-1}$ ). It is possible that surface frost crystals are a substantial source of secondary ice particles, with the potential to enhance ice concentrations by several orders of magnitude above that which might be expected based on the observed or predicted numbers of ice nuclei in the cloud.

Acknowledgements. This project was supported by the Natural Environment Research Council under grant NE/1028296/1. We would like to thank the International Foundation High Altitude Research Stations Jungfraujoch and Gornergrat (HFSJG) for providing the support in carrying out experiments at Jungfraujoch and the ACTRIS-TNA project for contributing towards the project infrastructure during 2013. We would also like to thank Maria and Urs Otz as well as Joan and Martin Fischer for their help during measurement periods.

Edited by: H. Grothe

\section{References}

Baltensperger, U., Schwikowski, M., Jost, D. T., Nyeki, S., Gäggeler, H. W., and Poulida, O.: Scavenging of atmospheric constituents in mixed phase clouds at the high-alpine site Jungfraujoch part I: basic concept and aerosol scavenging by clouds, Atmos. Environ., 32, 3975-3983, doi:10.1016/S13522310(98)00051-X, 1998.

Baumgardner, D., Jonsson, H., Dawson, W., O'Connor, D., and Newton, R.: The cloud, aerosol and precipitation spectrometer: a new instrument for cloud investigations, Atmos. Res., 59-60, 251-264, doi:10.1016/S0169-8095(01)00119-3, 2001.

Baumgardner, D., Newton, R., Krämer, M., Meyer, J., Beyer, A., Wendisch, M., and Vochezer, P.: The Cloud Particle Spectrometer with Polarization Detection (CPSPD): A next generation open-path cloud probe for distinguishing liquid cloud droplets from ice crystals, Atmos. Res., 142, 2-14, doi:10.1016/j.atmosres.2013.12.010, 2014.

Brown, P. and Francis, P.: Improved measurements of the ice water content in cirrus using a total-water probe, J. Atmos. Ocean. Tech., 12, 410-414, 1995.

Chou, C., Stetzer, O., Weingartner, E., Jurányi, Z., Kanji, Z. A., and Lohmann, U.: Ice nuclei properties within a Saharan dust event at the Jungfraujoch in the Swiss Alps, Atmos. Chem. Phys., 11, 4725-4738, doi:10.5194/acp-11-4725-2011, 2011.

Choularton, T. W., Bower, K. N., Weingartner, E., Crawford, I., Coe, H., Gallagher, M. W., Flynn, M., Crosier, J., Connolly, P., Targino, A., Alfarra, M. R., Baltensperger, U., Sjogren, S., Verheggen, B., Cozic, J., and Gysel, M.: The influence of small aerosol particles on the properties of water and ice clouds, Faraday Discuss., 137, 205-222, doi:10.1039/b702722m, 2008. 
Crawford, I., Bower, K. N., Choularton, T. W., Dearden, C., Crosier, J., Westbrook, C., Capes, G., Coe, H., Connolly, P. J., Dorsey, J. R., Gallagher, M. W., Williams, P., Trembath, J., Cui, Z., and Blyth, A.: Ice formation and development in aged, wintertime cumulus over the UK: observations and modelling, Atmos. Chem. Phys., 12, 4963-4985, doi:10.5194/acp-12-4963-2012, 2012.

Crosier, J., Bower, K. N., Choularton, T. W., Westbrook, C. D., Connolly, P. J., Cui, Z. Q., Crawford, I. P., Capes, G. L., Coe, H., Dorsey, J. R., Williams, P. I., Illingworth, A. J., Gallagher, M. W., and Blyth, A. M.: Observations of ice multiplication in a weakly convective cell embedded in supercooled mid-level stratus, Atmos. Chem. Phys., 11, 257-273, doi:10.5194/acp-11-257-2011, 2011.

DeMott, P. J., Prenni, A. J., Liu, X., Kreidenweis, S. M., Petters, M. D., Twohy, C. H., Richardson, M. S., Eidhammer, T., and Rogers, D. C.: Predicting global atmospheric ice nuclei distributions and their impacts on climate, P. Natl. Acad. Sci. USA, 107, 1121711222, doi:10.1073/pnas.0910818107, 2010.

Dye, J. and Baumgardner, D.: Evaluation of the forward scattering spectrometer probe. Part I: Electronic and optical studies, J. Atmos. Ocean. Tech., 1, 329-344, doi:10.1175/15200426(1984)001<0329:EOTFSS>2.0.CO;2, 1984.

Ebert, M., Worringen, A., Benker, N., Mertes, S., Weingartner, E., and Weinbruch, S.: Chemical composition and mixing-state of ice residuals sampled within mixed phase clouds, Atmos. Chem. Phys., 11, 2805-2816, doi:10.5194/acp-11-2805-2011, 2011.

Fugal, J. P., Schulz, T. J., and Shaw, R. A.: Practical methods for automated reconstruction and characterization of particles in digital inline holograms, Meas. Sci. Technol., 20, 075501, doi:10.1088/0957-0233/20/7/075501, 2009.

Gallagher, M., Choularton, T., Morse, A. and Fowler, D.: Measurements of the size dependence of cloud droplet deposition at a hill site, Q. J. Roy. Meteor. Soc., 114, 1291-1303, doi:10.1256/smsqj.48306, 1988.

Gallet, J.-C., Domine, F., Savarino, J., Dumont, M., and Brun, E.: The growth of sublimation crystals and surface hoar on the Antarctic plateau, The Cryosphere, 8, 1205-1215, doi:10.5194/tc-8-1205-2014, 2014.

Gerber, H.: Direct measurement of suspended particulate volume concentration and far-infrared extinction coefficient with a laser-diffraction instrument, Appl. Optics, 30, 4824-31, doi:10.1364/AO.30.004824, 1991.

Gordon, M. and Taylor, P. A.: Measurements of blowing snow, Part I: Particle shape, size distribution, velocity, and number flux at Churchill, Manitoba, Canada, Cold Reg. Sci. Technol., 55, 6374, doi:10.1016/j.coldregions.2008.05.001, 2009.

Griggs, D. and Choularton, T.: A laboratory study of secondary ice particle production by the fragmentation of rime and vapourgrown ice crystals, Q. J. Roy. Meteor. Soc., 112, 149-163, doi:10.1002/qj.49711247109, 1986.

Hallett, J. and Mossop, S. C.: Production of secondary ice crystals during the riming process, Nature, 249, 26-28, doi:10.1038/249026a0, 1974.

Henneberger, J., Fugal, J. P., Stetzer, O., and Lohmann, U.: HOLIMO II: a digital holographic instrument for ground-based in situ observations of microphysical properties of mixed-phase clouds, Atmos. Meas. Tech., 6, 2975-2987, doi:10.5194/amt-62975-2013, 2013.
Henneberger, J., Lloyd, G., Boose, Y., Vochezer, P., Fugal, J. P., Kanji, Z. A., and Lohmann, U.: Observation of orographic influenced mixed-phase clouds at the high alpine site Jungfraujoch, Switzerland, in preparation, 2015.

Kamphus, M., Ettner-Mahl, M., Klimach, T., Drewnick, F., Keller, L., Cziczo, D. J., Mertes, S., Borrmann, S., and Curtius, J.: Chemical composition of ambient aerosol, ice residues and cloud droplet residues in mixed-phase clouds: single particle analysis during the Cloud and Aerosol Characterization Experiment (CLACE 6), Atmos. Chem. Phys., 10, 8077-8095, doi:10.5194/acp-10-8077-2010, 2010.

Korolev, A. V., Isaac, G. A., Cober, S. G., Strapp, J. W., and Hallett, J.: Microphysical characterization of mixed-phase clouds, Q. J. R. Meteor. Soc., 129, 39-65, doi:10.1256/qj.01.204, 2003.

Korolev, A. V., Emery, E. F., Strapp, J. W., Cober, S. G., Isaac, G. A., Wasey, M., and Marcotte, D.: Small ice particles in tropospheric clouds: fact or artifact?, B. Am. Meteorol. Soc., 92, 967-973, doi:10.1175/2010BAMS3141.1, 2011.

Lachlan-cope, T., Ladkin, R., Turner, J., and Davison, P.: Observations of cloud and precipitation particles on the Avery Plateau, Antarctic Peninsula, Antarct. Sci., 13, 339-348, doi:10.1017/S0954102001000475, 2001.

Lance, S., Brock, C. A., Rogers, D., and Gordon, J. A.: Water droplet calibration of the Cloud Droplet Probe (CDP) and inflight performance in liquid, ice and mixed-phase clouds during ARCPAC, Atmos. Meas. Tech., 3, 1683-1706, doi:10.5194/amt3-1683-2010, 2010.

Lawson, P. R., O'Connor, D., Zmarzly, P., Weaver, K., Baker, B., and Mo, Q.: The 2D-S (stereo) probe: design and preliminary tests of a new airborne high-speed, high resolution particle imaging probe, J. Atmos. Ocean. Tech., 23, 1462-1477, doi:10.1175/JTECH1927.1, 2006.

Lloyd, G., Dearden, C., Choularton, T. W., Crosier, J., and Bower, K. N.: Observations of the Origin and Distribution of Ice in Cold, Warm, and Occluded Frontal Systems during the DIAMET Campaign, Mon. Weather Rev., 142, 4230-4255, doi:10.1175/MWRD-13-00396.1, 2014.

Lloyd, G., Choularton, T. W., Bower, K. N., Crosier, J., Jones, H., Dorsey, J. R., Gallagher, M. W., Connolly, P., Kirchgaessner, A. C. R., and Lachlan-Cope, T.: Observations and comparisons of cloud microphysical properties in spring and summertime Arctic stratocumulus clouds during the ACCACIA campaign, Atmos. Chem. Phys., 15, 3719-3737, doi:10.5194/acp-15-37192015, 2015.

Lohmann, U. and Feichter, J.: Global indirect aerosol effects: a review, Atmos. Chem. Phys., 5, 715-737, doi:10.5194/acp-5-7152005, 2005.

Mahesh, A., Eager, R., Campbell, J. R., and Spinhirne, J. D.: Observations of blowing snow at the South Pole, J. Geophys. Res., 108, 4707, doi:10.1029/2002JD003327, 2003.

Perovich, D. K. and Richter-Menge, J. A.: Surface Characteristics of Lead Ice, J. Geophys. Res., 99, 16341-16350, doi:10.1029/94JC01194, 1994.

Rangno, A. L.: Fragmentation of Freezing Drops in Shallow Maritime Frontal Clouds, J. Atmos. Sci., 65, 1455-1466, doi:10.1175/2007JAS2295.1, 2008.

Rangno, A. L. and Hobbs, P. V.: Ice particles in stratiform clouds in the Arctic and possible mechanisms for the produc- 
tion of high ice concentrations, J. Geophys. Res., 106, 15065, doi:10.1029/2000JD900286, 2001.

Rankin, A. M., Auld, V., and Wolff, E. W.: Frost flowers as a source of fractionated sea salt aerosol in the polar regions, Geophys. Res. Lett., 27, 3469-3472, doi:10.1029/2000GL011771, 2000.

Rogers, D. C. and Vali, G.: Ice Crystal Production by Mountain Surfaces, J. Clim. Appl. Meteorol., 26, 1152-1168, doi:10.1175/1520-0450(1987)026<1152:ICPBMS>2.0.CO;2, 1987.

Schlenczek, O., Fugal, J., Bower, K. N., Crosier, J., Flynn, M. J., Henneberger, J., Lloyd, G., Krieger, U. K., and Borrmann, S.: Atmospheric ice crystals over complex terrain: Pure ice cloud conditions observed in CLACE2013 at Jungfraujoch, Switzerland, European Geosciences Union, 2015.

Schmidt, S., Schneider, J., Klimach, T., Mertes, S., Schenk, L. P., Curtius, J., Kupiszewski, P., Hammer, E., Vochezer, P., Lloyd, G., Ebert, M., Kandler, K., Weinbruch, S., and Borrmann, S.: In-situ single submicron particle composition analysis of ice residuals from mountain-top mixed-phase clouds in Central Europe, Atmos. Chem. Phys. Discuss., 15, 4677-4724, doi:10.5194/acpd15-4677-2015, 2015.

Targino, A. C., Coe, H., Cozic, J., Crosier, J., Crawford, I., Bower, K., Flynn, M., Gallagher, M., Allan, J., Verheggen, B., Weingartner, E., Baltensperger, U., and Choularton, T.: Influence of particle chemical composition on the phase of cold clouds at a high-alpine site in Switzerland, J. Geophys. Res., 114, 1-20, doi:10.1029/2008JD011365, 2009.
Vali, G., Leon, D., and Snider, J. R.: Ground-layer snow clouds, Q. J. Roy. Meteorol. Soc., 138, 1507-1525, doi:10.1002/qj.1882, 2012.

Vardiman, L.: The generation of secondary ice particles in clouds by crystal-crystal collision, J. Atmos. Sci., 35, 2162-2180, doi:10.1175/1520-0469(1978)035<2168:TGOSIP>2.0.CO;2, 1978.

Wagner, R. and Möhler, O.: Enhanced high-temperature ice nucleation ability of crystallized aerosol particles after preactivation at low temperature, J. Geophys. Res., 119, 8212-8230, doi:10.1002/2014JD021741, 2014.

Xu, L., Russell, L. M., Somerville, R. C. J., and Quinn, P. K.: Frost flower aerosol effects on Arctic wintertime longwave cloud radiative forcing, J. Geophys. Res.-Atmos., 118, 13282-13291, doi:10.1002/2013JD020554, 2013.

Yano, J. I. and Phillips, V. T. J.: Ice-Ice Collisions: An Ice Multiplication Process in Atmospheric Clouds, J. Atmos. Sci., 68, 322-333, doi:10.1175/2010JAS3607.1, 2011. 